\title{
Cycle analysis of MCFC/gas turbine system
}

\author{
Abdullatif Musa $^{1, *}$, Abdulsalam Alaktiwi ${ }^{1}$, and Mosbah Talbi ${ }^{1}$ \\ ${ }^{1}$ University of Tripoli, Faculty of Engineering, Department of Marine Engineering, Tripoli, Libya
}

\begin{abstract}
High temperature fuel cells such as the solid oxide fuel cell (SOFC) and the molten carbonate fuel cell (MCFC) are considered extremely suitable for electrical power plant application. The molten carbonate fuel cell (MCFC) performances is evaluated using validated model for the internally reformed (IR) fuel cell. This model is integrated in Aspen Plus ${ }^{\mathrm{TM}}$. Therefore, several MCFC/Gas Turbine systems are introduced and investigated. One of this a new cycle is called a heat recovery (HR) cycle. In the HR cycle, a regenerator is used to preheat water by outlet air compressor. So the waste heat of the outlet air compressor and the exhaust gases of turbine are recovered and used to produce steam. This steam is injected in the gas turbine, resulting in a high specific power and a high thermal efficiency. The cycles are simulated in order to evaluate and compare their performances. Moreover, the effects of an important parameters such as the ambient air temperature on the cycle performance are evaluated. The simulation results show that the HR cycle has high efficiency.
\end{abstract}

\section{Introduction}

Fuel cells are electrochemical energy conversion devices which typically run on hydrogen or methane or methanol and produce electricity, heat and benign emissions (water and, in the case of methane and methanol, $\mathrm{CO}_{2}$ ). The fuel cells used for stationary energy production are typically high temperature fuel cells (HTFCs) such as and molten carbonate fuel cell (MCFC).

MCFC technology was established about 30 years ago and has been developed considerably fast in the USA, Korea, Japan and Europe during the last 10 years. In the literature there have been several studies published on MCFC systems and their analyses [1-7].

In [1] a system modeling was carried out to compare different schemes for the molten carbonate fuel cell (MCFC) technology for an auxiliary power unit (APU) purposes in the marine field. The reference plant had a power of $500 \mathrm{kWe}$ provided by the full cell (FC) stack, plus roughly $100 \mathrm{kWe}$ from a gas turbine. The results were compared to the power needs and raw materials on-board stock capabilities of three reference cases of commercial ships. Considering the size of the selected ships, these could profitably benefit of high efficiency MCFCs for APU purposes, without major ship plant adjustments for feeding the

\footnotetext{
*Corresponding author: a.musa@na.uot.ly
} 
required diesel oil, while demi-water needs to be recycled within the APU to make the latter less impacting on the ship infrastructure.

In this paper thermodynamic model for internally reformed MCFC is developed. Moreover, newly multistage (MS) and heat recovery (HR) cycles are introduced: the multistage cycle consisting of two stages of compression with intercooling and two stages expansion with reheating. Moreover in the heat recovery (HR) cycle, the air leaving the first stage compressor is at high temperature. This temperature is higher than the inlet intercooler temperature. Therefore, a regenerator is used to preheat water by outlet air compressor. The waste heat of the outlet air compressor and the exhaust gases of turbine are recovered and used to produce steam, this steam is injected in the gas turbine, resulting in a high specific power and a high efficiency of the HR cycle.

South Tripoli Gas Power Plant is one of the network feeder plants in Tripoli, Libya . The power plant was constructed by ABB a German-Swiss company in 1994, and it consists of five gas turbine power units. One of the gas turbine power unit GT 14 selected as a basic cycle for this study. The ambient temperature in Libya may reach $40 \mathrm{C}$ in summer. So it is an important to study effects of ambient temperature changes on the performance of the introduced cycles. The aim of this work is to find the best configuration for a several cycles. Therefore, the basic ,multistage and heat recovery cycles are simulated in order to evaluate and compare their performances.

\section{Configuration cycle description}

The high temperature inside the cells stack allows for reforming the methane $\left(\mathrm{CH}_{4}\right)$ directly inside the cell if the steam is provided at the inlet. The heat necessary for this reforming reaction is delivered by the electrochemical reaction in the cell. The gas turbine unit GT14 of south Tripoli gas turbine power plant is selected as a basic cycle for this study. This power plant was constructed by ABB a German-Swiss company in 1994. The basic cycle consists of compressor, combustion chamber, and gas turbine. The compressed air enters the combustion chamber, where its burned at essentially constant pressure. The gasses is expanded at the gas turbine until they reach the ambient pressure.

\subsection{Multistage cycle configuration}

The multistage (MS) cycle configuration consisting of two stages of compression with intercooling and two stages expansion with reheating. Moreover, this cycle consisting of the MCFC stack. The compressed air from the compressor (AC1) is split into two parts. Part of the air is sent to the intercooler, the second stage compressor (AC2), the combustor (comb1) and the gasses is expanded at the high pressure gas turbine (GT1). The remaining part of the air is mixed with the exhaust gasses of GT1 and then enters the MCFC stack. By considering that, the MCFC stack exit gasses which contains a major part of air, and $\mathrm{CH}_{4}$ are sent to the second combustor (Comb2) and the low pressure gas turbine (GT2) (see Fig. 1a).

\subsection{Heat recovery cycle configuration}

The heat recovery (HR) cycle is similar to the multistage cycle (Fig. 1a), except that, the air leaving the first stage compressor (AC1) is at high temperature, so regenerator (HE1) is used to preheat water by the outlet air compressor (AC1). The waste heat of the major outlet air compressor (AC1) and the exhaust gasses of gas turbine (GT2) are recovered and 
used to produce steam. This steam is injected in the high pressure gas turbine (GT1) (see Fig. 1b).

\section{Water gas shift and methane reforming reactions}

The chemical reactions occur in the model are assumed to be in equilibrium. The electrochemical reaction is implemented as the following:

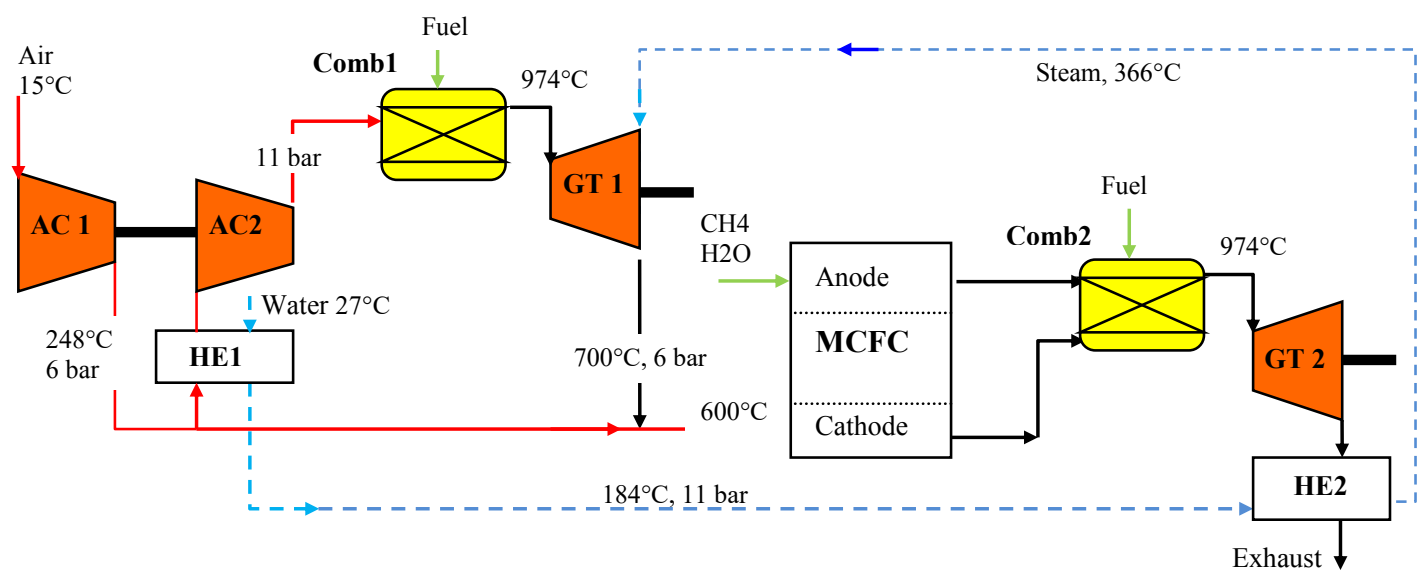

Fig.1. The MCFC/gas turbine cycles: layout A and B (the dotted line is for B).

Table 1. Setting parameters of the cycle.

\begin{tabular}{|c|c|c|c|}
\hline Setting parameter & Value & Setting parameter & Value \\
\hline Current density & $0.250 \mathrm{Acm}^{-2}$ & Pressure ratio & 11 \\
\hline Active cell area & $250 \mathrm{~m}^{2}$ & $\begin{array}{c}\text { Pressure drop in } \\
\text { combustor }\end{array}$ & $0.2 \mathrm{bar}$ \\
\hline Total fuel utilisation rate & $85 \%$ & Pressure drop in MCFC & $0.05 \mathrm{bar}$ \\
\hline $\begin{array}{c}\text { Compressors isentropic } \\
\text { efficiency }\end{array}$ & $80 \%$ & $\begin{array}{c}\text { Pressure drop in heat } \\
\text { exchangers }\end{array}$ & $0.02 \mathrm{bar}$ \\
\hline $\begin{array}{c}\text { Gas turbine and pump } \\
\text { isentropic efficiencies }\end{array}$ & $85 \%$ & $\begin{array}{c}\text { Gas turbine and } \\
\text { compressor mechanical } \\
\text { efficiencies }\end{array}$ & $98 \%$ \\
\hline Fuel flow rate & $6.349 \mathrm{~kg} / \mathrm{s}$ & Air flow rate & $394.5 \mathrm{~kg} / \mathrm{s}$ \\
\hline
\end{tabular}

$$
\begin{gathered}
\mathrm{CO}_{2}+\frac{1}{2} \mathrm{O}_{2}+2 e^{-} \rightarrow \mathrm{CO}_{3}^{2-} \text { cathode } \\
\mathrm{H}_{2}+\mathrm{CO}_{3}^{2-} \rightarrow \mathrm{H}_{2} \mathrm{O}+\mathrm{CO}_{2}+2 e^{-} \text {anode } \\
\mathrm{H}_{2}+\frac{1}{2} \mathrm{O}_{2} \rightarrow \mathrm{H}_{2} \mathrm{O} \text { overall reaction }
\end{gathered}
$$

The MCFC stack operate at a temperature high enough to reform the steam reforming inside the anode. The electrochemical and water gas shift reactions are exothermic and, on the other hand, the methane reforming reaction is a strongly endothermic reaction. The chemical reactions in the steam reforming and water gas shift are shown below: 


$$
\begin{gathered}
\mathrm{CH}_{4}+\mathrm{H}_{2} \mathrm{O} \Leftrightarrow \mathrm{CO}+3 \mathrm{H}_{2} \\
\mathrm{CO}+\mathrm{H}_{2} \mathrm{O} \Leftrightarrow \mathrm{CO}_{2}+\mathrm{H}_{2}
\end{gathered}
$$

In case of IR-MCFC the equilibrium molar flow rate along the anode and cathode can be calculated using the stoichiometric balance of the steam reforming, water shift and electrochemical reactions. So the mole fractions along the anode and cathode can be calculated as follows:

$$
\gamma_{C H_{4}}=\frac{\dot{n}_{C H_{4}}}{\dot{n}_{t o t, a n}}=\frac{\dot{n}_{C_{4}, \text { inlet }}-x}{\dot{n}_{a n}+2 x+z}
$$

where: $\dot{n}_{a n}=\dot{n}_{C H_{4} \text { inlet }}+\dot{n}_{H_{2} O \text {,inlet }}+\dot{n}_{C O \text {,inlet }}+\dot{n}_{H_{2}, \text { inlet }}+\dot{n}_{C_{0} O_{2 n} \text {,inlet }}+\dot{n}_{N_{2, a n}}$ is the inlet molar flow rate of the mixture at the anode input

$$
\begin{aligned}
& \gamma_{\mathrm{H}_{2} \mathrm{O}}=\frac{\dot{n}_{\mathrm{H}_{2} \mathrm{O} \text {, inlet }}-x-y+z}{\dot{n}_{a n}+2 x+z} \\
& \gamma_{C O}=\frac{\dot{n}_{C O, \text { inlet }}+x-y}{\dot{n}_{a n}+2 x+z} \\
& \gamma_{H_{2}}=\frac{\dot{n}_{H_{2}, \text { inlet }}+3 x+y-z}{\dot{n}_{a n}+2 x+z} \\
& \gamma_{\mathrm{CO}_{2} a n}=\frac{\dot{n}_{\mathrm{CO}_{2} a n, \text { inlet }}+y+z}{\dot{n}_{a n}+2 x+z} \\
& \gamma_{N_{2}, a n}=\frac{\dot{n}_{N_{2}, a n}}{\dot{n}_{a n}+2 x+z} \\
& \gamma_{O_{2}}=\frac{\left(\dot{n}_{O_{2}, \text { inlet }}-z / 2\right)}{\left(\dot{n}_{c a}-\left(\frac{3 z}{2}\right)\right)}
\end{aligned}
$$

where: $\dot{n}_{c a}=\dot{n}_{O_{2} \text {,inlet }}+\dot{n}_{\mathrm{CO}_{2} \text { ca,inlet }}+\dot{n}_{\mathrm{N}_{2}}$ is the molar flow rate of the mixture at the cathode input

$$
\begin{aligned}
& \gamma_{\mathrm{CO}_{2} c a}=\frac{\left(\dot{n}_{\mathrm{CO}_{2} c a, \text { inlet }}-z\right)}{\left(\dot{n}_{c a}-\left(\frac{3 z}{2}\right)\right)} \\
& \gamma_{N_{2}}=\frac{\dot{n}_{N_{2}}}{\left(\dot{n}_{c a}-\left(\frac{3 z}{2}\right)\right)}
\end{aligned}
$$

The electrochemical, steam reforming and water gas shift reactions rates should be calculated using the definitions of equilibrium constant of the steam reforming $\left(K_{f}\right)$, equilibrium constant of the water gas $\operatorname{shift}\left(K_{p}\right)$, and fuel utilization factor $(Z)$ as follows:

$$
K_{f}=\frac{\left(\dot{n}_{H_{2}, \text { inlet }}+3 x+y-z\right)^{3}\left(\dot{n}_{C O, \text { inlet }}+x-y\right)}{\left(\dot{n}_{\mathrm{CH}_{4}, \text { inlet }}-x\right)\left(\dot{n}_{\mathrm{H}_{2} \mathrm{O}, \text { inlet }}-x-y+z\right)}\left(\frac{p_{a n}}{\dot{n}_{a n}+2 x+z}\right)^{2}
$$




$$
\begin{aligned}
K_{p} & =\frac{\left(\dot{n}_{H_{2}, \text { inlet }}+3 x+y-z\right)\left(\dot{n}_{\mathrm{CO}_{2} \text { an, inlet }}+y+z\right)}{\left(\dot{n}_{\mathrm{CO}, \text { inlet }}+x-y\right)\left(\dot{n}_{\mathrm{H}_{2} \mathrm{O}, \text { inlet }}-x-y+z\right)} \\
z & =u_{f}\left(\dot{n}_{\mathrm{H}_{2} \text { in }}+\dot{n}_{\mathrm{CO} \text { in }}+4 \dot{n}_{\mathrm{CH}_{4} \text { in }}\right)
\end{aligned}
$$

Please note that, the values of ( $x, y$ and $z$ ) are unknowns, but they can be determined by solving equations (15), (16) and (17).

\section{MCFC model description}

The fuel cell is treated as a single control volume in which the steady state flow energy equation is applied with the assumption of negligible change of kinetic energy and potential energy. To determine actual cell performance, the overpotential must be deducted from the Nernst potential $(E)$ which represents the ideal performance.

$$
V_{\text {cell }}=E-V_{\text {loss }}
$$

The internal resistances of the MCFC stack can be calculated as in [5]. But the ohmic cell $\left(r_{\text {ohm }}\right)$, anodic reaction $\left(r_{p o l, a n}\right)$ and cathodic reaction $\left(r_{p o l, c a}\right)$ resistances are reflected in the functions of the reaction temperatures and partial pressure of gas constituents. Please note that, the Ohmic cell resistance is calculated using an Arrhenius equation as function of the operating temperature.

$$
\begin{gathered}
r_{\text {ohm }}=0.5 \exp \left[3016 \times\left(\frac{1}{T_{\text {cell }}}-\frac{1}{923}\right)\right] \\
r_{\text {pol,an }}=2.27 \times 10^{-5} \exp \left(\frac{6435}{T_{\text {cell }}}\right) P_{H_{2}}^{-0.42} P_{\mathrm{CO}_{2}}^{-0.17} P_{H_{2} \mathrm{O}}^{-1} \\
r_{\text {pol,ca }}=7.505 \times 10^{-6} \exp \left(\frac{9298}{T_{\text {cell }}}\right) P_{O_{2}}^{-0.34} P_{\text {CO2 }}^{-0.09}
\end{gathered}
$$

The stack cell voltage can be found by using the following equation

$$
V_{\text {cell }}=\frac{R T}{2 F} \ln K-\frac{R T}{2 F} \ln \left(\frac{p_{\mathrm{H}_{2} \mathrm{O}} p_{\mathrm{CO}_{2} a n}}{p_{\mathrm{H}_{2}} p_{\mathrm{CO}_{2} \mathrm{ca}} \sqrt{p_{\mathrm{O}_{2}}}}\right)-i \times\left(r_{\text {ohm }}+r_{p o l, a n}+r_{p o l, c a}\right)
$$

The electrical power produced by the fuel cell is calculated by:

$$
W=V_{\text {cell }} I
$$

The cycle efficiency $\left(\eta_{\text {Cycle }}\right)$ is defined as the ratio of the power produced by the fuel cells $\left(W_{M C F C}\right)$ and the total gas turbines, minus the total compressor power, to the ( $L H V$ ) of the total amount of fuel $\left(Q_{t o t}\right)$

$$
\eta_{\text {Cycle }}=\frac{W_{M C F C}+W_{\text {turbs }}-W_{\text {comps }}}{Q_{\text {tot }}}
$$




\section{Results and discussion}

The cycle's layout under investigation is simulated under the standard operating conditions shown in table 1 . The gas turbine unit GT14 of south Tripoli gas turbine power plant, Tripoli, Libya is selected as a basic cycle (basic cycle) for this study. The multistage (MS) cycle and the heat recovery (HR) cycle are introduced in this work. The MS cycle consisting of two stages of compression with intercooling and two stages expansion with reheating. In the HR cycle, the air leaving the first stage compressor is at high temperature, and this temperature is higher than the inlet intercooler temperature. Therefore, regenerator is used to preheat water by outlet air compressor. The waste heat of the outlet air compressor and the exhaust gases of turbine are recovered and used to produce steam. This steam is injected in the gas turbine. The aim of this analysis is to investigate and compared the performance of the cycles. As it's known, the temperature and cell voltage are the core of any fuel cell modeling and gas turbine cycle, and referring to the flow sheets shown in Fig.1. The effect of the ambient temperature on the performances of the cycles are investigated.

Fig. 2 shows the changes in the specific work of the basic cycle with the ambient temperature. Increasing the ambient temperature decreases the inlet air density, resulting an increase of the specific work of the compressor (Wcomp1). The increase in the specific work of the compressor causes the decrease in the specific net work of the cycle (Wnet). There is no effect of the ambient temperature on the specific work of the gas turbine (WGT). Fig. 3 shows the changes in the specific net work of the cycles with the ambient temperature. The multistage (MS) and heat recovery (HR) cycles have a higher specific network. This is mainly caused by the reduction of the specific compressor (AC1) work (see Fig.4). In the HR cycle, the waste heat of the major outlet air AC1 and the exhaust gases of gas turbine (GT2) are recovered and used to produce steam and then is injected in GT1. This means the gas turbine power of the HR cycle is higher than of the MS cycle (see Fig. 5). The increase in the power of gas turbine in the HR cycle is caused by the mass flow rate of steam which is injected and expanded in the GT1.

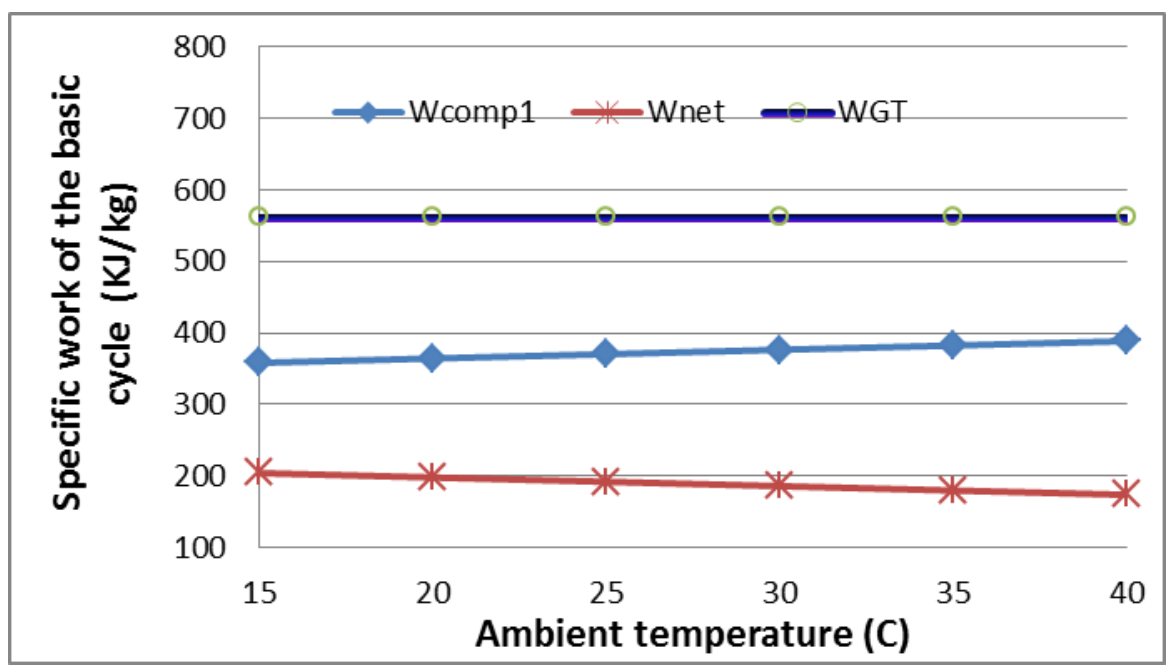

Fig. 2. The changes in the specific work of the basic cycle with the ambient temperature. 


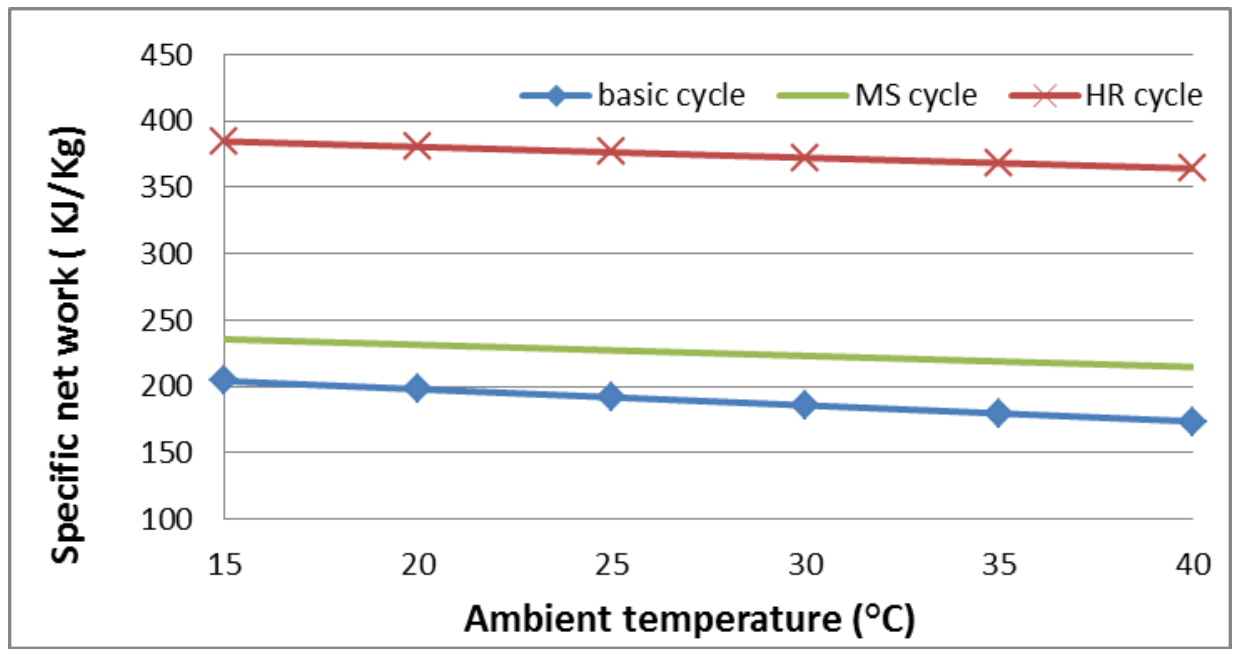

Fig. 3. The changes in the specific net work of the cycles with the ambient temperature.

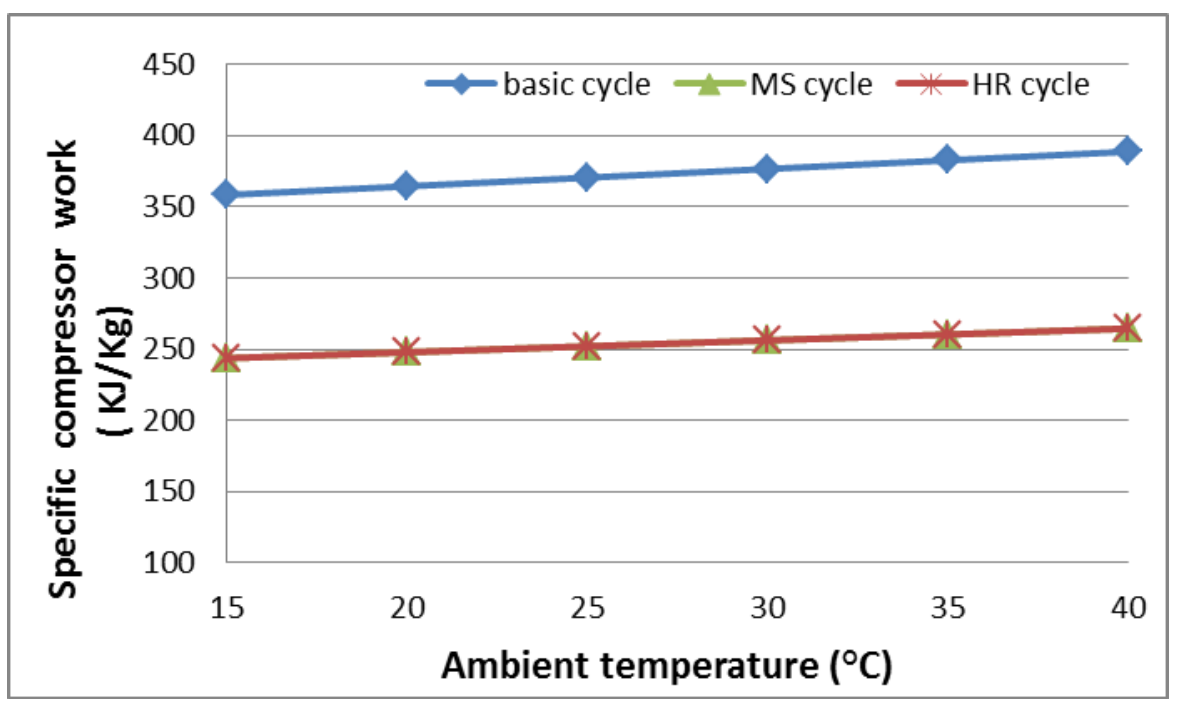

Fig. 4. The changes in the specific compressor (AC1) work of the cycles with the ambient temperature. 


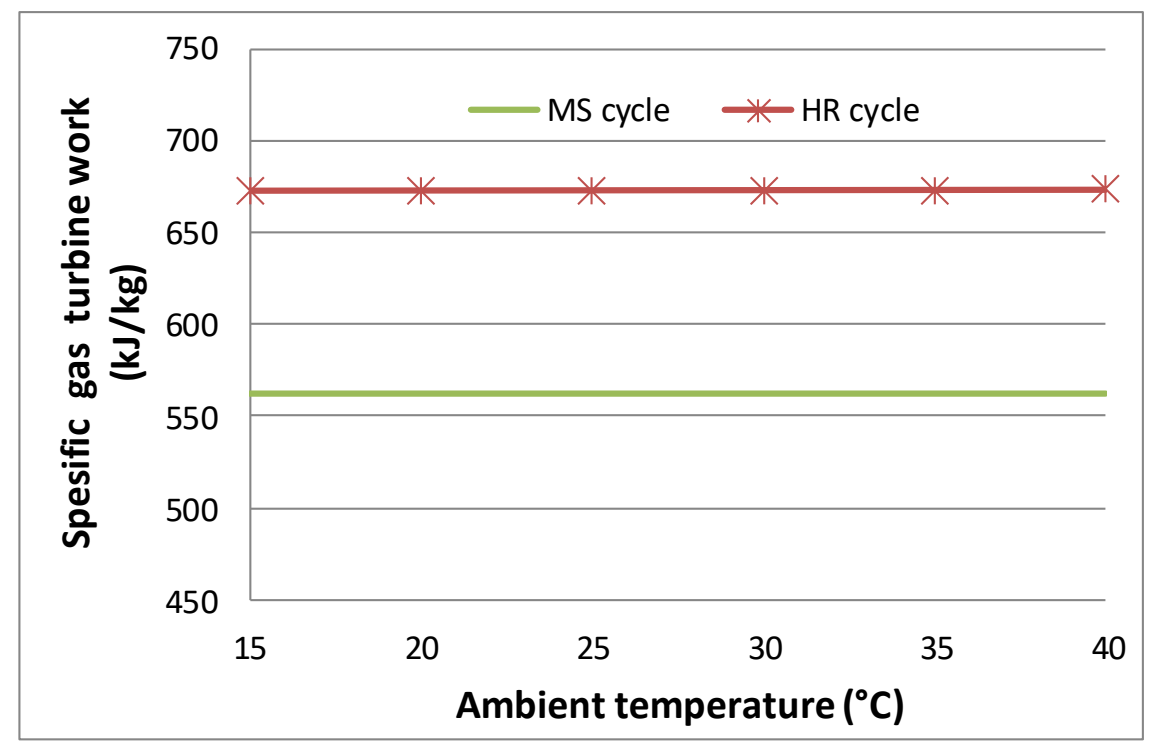

Fig. 5. The changes in the specific gas turbine work of the cycles with the ambient temperature.

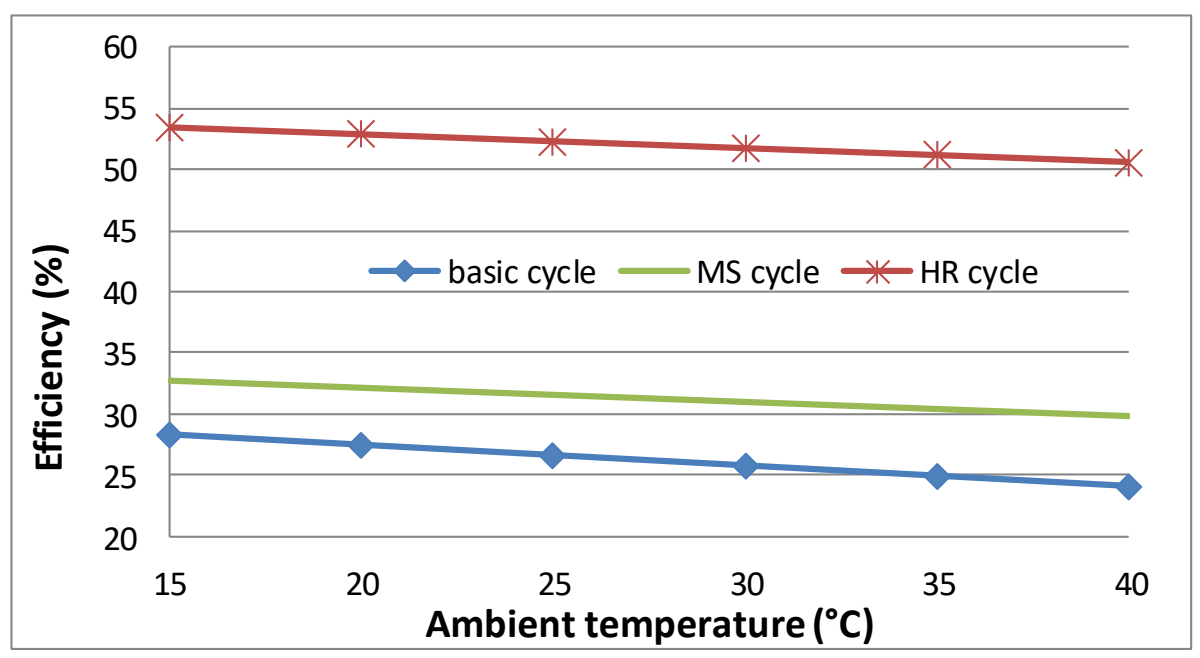

Fig. 6. the changes in the efficiency of the cycles with the ambient temperature.

Fig. 6 shows the changes in the efficiency of the cycles with the ambient temperature. The efficiency of the MS and HR cycles is higher than of the basic cycle. Though the total fuel consumption is higher in the MS and HR cycles, the power of fuel cell stack and gas turbines is also higher, causing the increase in efficiency. The efficiency of the HR cycle is higher than of the MS cycle, because of the recuperation of the waste heat of the major outlet air AC1 and the exhaust gasses of gas turbine (GT2). As more mass flow rate of steam is injected in the high pressure gas turbine, more power can be produced resulting in an increase of the HR cycle efficiency and a decrease of the exhaust gasses temperature (see Fig. 7). 


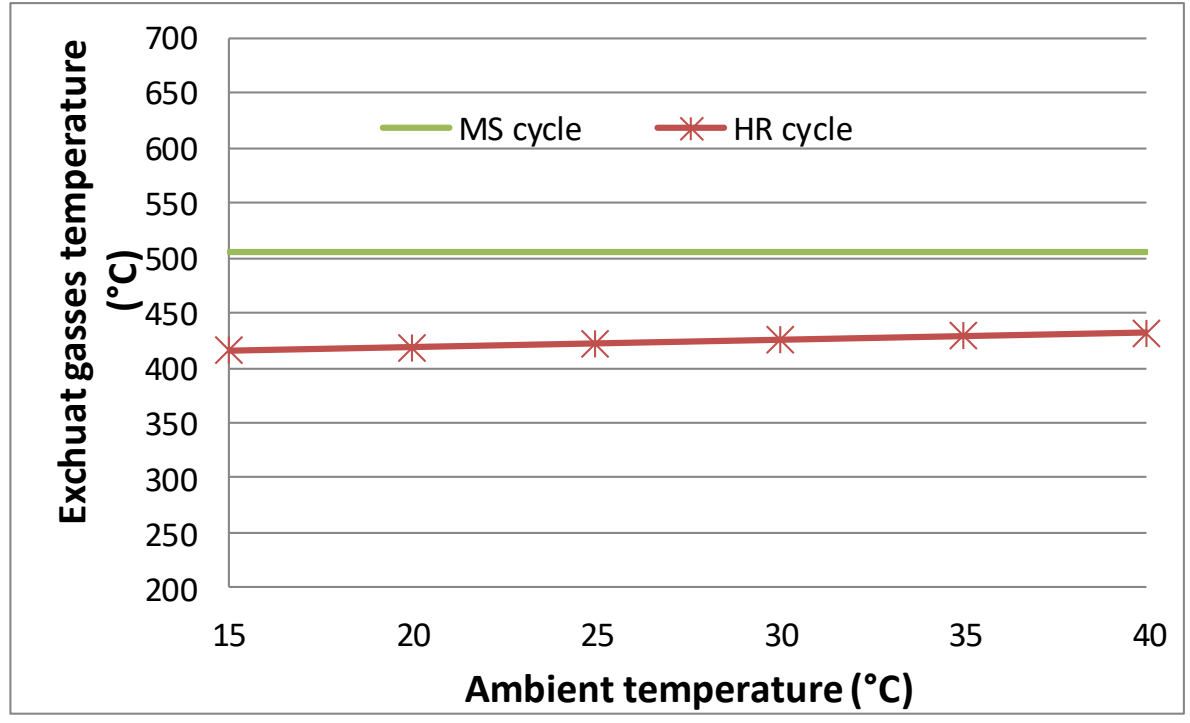

Fig. 7. Exhaust gasses temperature of the cycles as a function of the ambient temperature.

\section{Conclusions}

High temperature fuel cells such as the solid oxide fuel cell (SOFC) and the molten carbonate fuel cell (MCFC) are considered extremely suitable for electrical power plant application.The molten carbonate fuel cell (MCFC) performances is evaluated using validated models for the internally reformed (IR) fuel cells. This model is integrated in Aspen Plus ${ }^{\mathrm{TM}}$. Therefore, several MCFC/Gas Turbine cycles are proposed and investigated. The gas turbine power unit GT14 of south Tripoli gas turbine power plant Tripoli, Libya is selected as a basic cycle for this study. Moreover, a new cycles are introduced: a multistage (MS) a heat recovery (HR) cycles. The MS cycle consisting of two stages of compression with intercooling and two stages expansion with reheating. In the HR cycle, the air leaving the first stage compressor is at high temperature. This temperature is higher than the inlet intercooler temperature. Therefore, a regenerator is used to preheat water by outlet air compressor. The waste heat of the outlet air compressor and the exhaust gases of turbine are recovered and used to produce steam. This steam is injected in the gas turbine, resulting in a high specific power and a high thermal efficiency. The basic ,multistage and heat recovery cycles are simulated in order to evaluate and compare their performances. Moreover, the effects of an important parameters such as the ambient air temperature on the system performance are evaluated. The results indicated that, an increasing the ambient temperature decreases the inlet air density, resulting an increase of the specific work of the compressor. The results indicate that the efficiency is higher in case of the MS and HR cycles compared to the basic cycle for the same ambient temperature. The highest specific work and cycle efficiency are on the contrary obtained for the HR cycle. As more mass flow rate of steam is injected in the high pressure gas turbine, more power can be produced resulting in an increase of the HR cycle efficiency. The recuperation of the waste heat of the major outlet air AC1 and the exhaust gases of gas turbine (GT2) is benefited to the HR cycle. 
The authors acknowledge Tripoli University, Tripoli, Libya for the support of this work.

\section{References}

1. S. Bensaid, S. Specchia, F. Federici, I. J. Hyd. Ener. 34, 2026-2042 (2009)

2. T. Araki, T. Ohba, S. Takezawa, K. Onda, Y. Sakaki, Pow. Sour. J. 158, 52-59 (2006)

3. A. Musa, M. De Paepe, I. J. Hyd. Ener. 33, 4665-4672 (2008)

4. S. Kimijima, N. Kasagi, JSME. J. series B, 48-1 (2005)

5. V. Verda, F. Nicolin, I. J. Hyd. Ener. 35, 794-806 (2010)

6. E. Bocci, F. Orecchini, A. Di Carlo, Pow. Sour. J. 160, 835-841 (2006)

7. A. Musa, H. Steeman, M. De Paepe, ASME. J. 4, 65-71 (2007)

8. M. Baranak, H. Atakül, Pow, Sour. J. 172, 831-839 (2007) 